\title{
Impact of agriculture irrigation on the habitat structure and use by Great Bustards (Otis tarda) in a NATURA 2000 site
}

\author{
Péter SPAKOVSZKY* \& Rainer RAAB
}

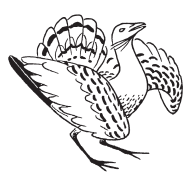

Received: October 16, 2020 -Revised: November 09, 2020 -Accepted: November 11, 2020

Spakovszky, P. \& Raab, R. 2020. Impact of agriculture irrigation on the habitat structure and use by Great Bustard (Otis tarda) in a NATURA 2000 site. - Ornis Hungarica 28(2): 74-84. DOI: 10.2478/orhu-2020-0018

\begin{abstract}
As the whole Palearctic steppe system, its iconic bird, the Great Bustard has also suffered from the expansion of intensive agriculture. The species now typically has stable or growing populations only in protected areas, but negative processes are still prevalent even there. In this study, we present a recent change in a part of the Natura 2000 site designated for the isolated West Pannonian population. In recent years, a total of $2.3 \mathrm{~km}$ Center-pivot and laterally moving linear irrigation systems have been built and $4.7 \mathrm{~km}$ of underground pipelines have been laid, with which more than $52 \%$ of the 1245,5 ha study area was irrigated by 2020 . In comparison to 2009 , when the study period has started, the sown area of autumn cereals, one of the main breeding habitats, was roughly halved and the proportion of crops unsuitable for breeding was increased. New crops requiring irrigation have emerged with a rate of $30.6 \%$ in the last year. Despite the available support, the area of alfalfa, which is the most significant breeding habitat, and is grown almost exclusively in the agri-environmental scheme, has decreased. As a result of habitat degradation, the number of Great Bustard females observed in the area in spring decreased to a small fraction of the beginning. Irrigation farming is expected to increase, as a response to the climate change, but in order to save agro-steppe habitats and their species, the adverse effects of agricultural intensification need to be urgently addressed at both local and European levels.
\end{abstract}

Keywords: intensive agriculture, agri-environmental scheme, agro-steppe habitat, West Pannonian Great Bustard population, agricultural policy

Összefoglalás Ahogy a palearktikus sztyepp övezet egésze, úgy annak emblematikus madara, a túzok is elszenvedte az intenzív mezőgazdálkodás elterjedését. A fajnak ma már jellemzően csak védett területen vannak stabil vagy növekvő állományai, de negatív folyamatok még ott is jellemzőek. A tanulmányunkkal az elszigetelödött nyugat-pannon populáció számára kijelölt NATURA 2000 terület egy részén, a közelmúltban bekövetkezett változást mutatjuk be. Az 1245,5 ha nagyságú vizsgálati területen az utóbbi években 2,3 km összhosszúságú forgó és oldalazó lineár öntözöberendezést építettek, illetve 4,7 km hosszan hidránsrendszereket fektettek, melyekkel 2020-ban a terület 52\%-át öntözték. Ennek hatására 2009-hez, vagyis a vizsgálati időszak kezdetéhez képest az egyik fő költőhabitat, az őszi gabonák vetésterülete nagyjából a felére csökkent, és nőtt a költésre alkalmatlan élöhelyek aránya. Új, öntözést igénylö növénykultúrák jelentek meg, melyek területi részaránya az utolsó évben már $30,6 \%$ volt. Az elérhető támogatás ellenére csökkent a költőhelyként jelentős lucerna vetésterülete, melyet szinte csak az agrár-környezetgazdálkodási program miatt termesztenek. Az élőhely romlásának következményeként a területen tavasszal megfigyelhető túzoktyúkok száma a korábbi töredékére esett. A klímaváltozás hatására várható az öntözéses gazdálkodás terjedése, de az agrár-sztyepp élőhelyek és fajaik megmentése érdekében a mezőgazdaság intenzifikációjának káros hatásait sürgősen kezelni kell mind helyi, mind európai szinten.

Kulcsszavak: intenzív mezőgazdaság, agrár-környezetgazdálkodás, agro-sztyepp élőhely, nyugat-pannon túzokállomány, agrárpolitika 


\section{Introduction}

Agriculture is the primary cause of biodiversity loss worldwide (Dudley \& Alexander 2017). One of the most endangered habitats by land use is the Palearctic steppe (Török et al. 2020). In addition to the loss of original habitats, the population of species that can adapt somewhat to the changed conditions (so-called farmland birds) is affected also by the intensity of farming in cultivated areas (Donald et al. 2001, Reidsma et al. 2006, Jerrentrup et al. 2017, Traba \& Morales 2019). This is especially true for species that are specialized for open habitats (Teillard et al. 2015). Irrigation is one of the most common elements of intensive farming practice, and in areas where it is widespread, steppe bird populations are in a less favorable position (Brotons et al. 2004, De Frutos et al. 2015).

The Great Bustard is an emblematic bird of the agro-steppe habitat, and it has also suffered the negative effects of the spread of intensive agriculture (Horreo et al. 2013). It bred in many European countries in the Middle Ages (Glutz et al. 1973), since then only isolated populations have survived (Szabó et al. 2007, Alonso et al. 2009a), and the primary reason for the eradication of countless populations was the agricultural activity (Alonso et al. 2003, Faragó 2006, Alonso 2014). Today, stable or possibly growing populations occur only in areas of comparatively better quality, that are usually protected, where near-natural habitats can also be found among patches of arable land (Pinto et al. 2005, Pitra et al. 2011, Szenek \& Végvári 2018), or where significant habitat protection measures have been taken to repress intensive farming, typically by launching an agri-environmental scheme (AES hereinafter) (Martín et al. 2012a, Alonso 2014, Faragó et al. 2014, Raab et al. 2014b), but usually the two are present together.

In agricultural areas, irrigation is particularly detrimental to habitat quality, which also affects Great Bustards. An abundance model tested in Spain (Martín et al. 2012b) showed that non-irrigated herbaceous vegetation cover was higher in places visited by Great Bustards than in places where the species was absent, and one of the defining component of the final abundance model was the non-irrigated area. This was confirmed by a study from Gameiro et al. (2020) showing that the abundance of Great Bustards is highly dependent on the extent of the agro-steppe habitat in the Iberian Peninsula, and the recent negative change affecting these habitats was the expansion of plantations and irrigated crops. Moreover, a significant reduction or extinction of some Portuguese Great Bustard populations was largely due to irrigation (Pinto et al. 2005).

The world's largest nature conservation network, the NATURA 2000 network, has been established to protect Europe's endangered habitats and species in order to eliminate harmful processes such as those mentioned above. When designing the network, the Great Bustards received special attention and the 91 Special Protected Areas (SPA) designated for the species under the Birds Directive cover the core areas of the species' most important habitats (EC 2009).

Recently, the burgeon of irrigated crop production in Hungary has accelerated, sometimes even affecting protected areas. This trend is significantly catalyzed by a large-scale agricultural irrigation development program (Hungarian Government 2017). In the present study, we demonstrate what negative change irrigation farming causes in the breeding site of an isolated Great Bustard population, using a particular example. 


\section{Material and method}

\section{Study species and area}

The global population of our study species, the Great Bustard amounts to 44,000 57,000 individuals (Alonso 2014) and is classified as vulnerable (BirdLife International 2020). The size of the isolated West Pannon population exceeds 600 individuals (Raab et al. 2010. Faragó et al. 2014 and own data), whose central habitat is located in the area of the Hungarian-Austrian-Slovak triple border (Raab et al. 2010). Natura 2000 sites have been designated in all three countries, which intersect along national borders. The study area is the most northern continuous part of the Moson Plain NATURA 2000 site (HUFH10004) in Hungary, which is mainly in conventional field cultivation (Figure 1). It is bordered on the east by a motorway, on the north-west by the Slovak and Austrian state borders, and on the south-west by fallow lands, a planted forest and, on a short section, a canal. It covers an area of 1245.5 hectares. Here, the calcareous chernozem soil is typical, which is excellent for crop production, although due to the shallow soil layer, the crops can suffer from drought early, but with the application of irrigation, however, it is easy and safe to achieve good yields even in dry years (Miklay \& Molnár 1968). The main crops

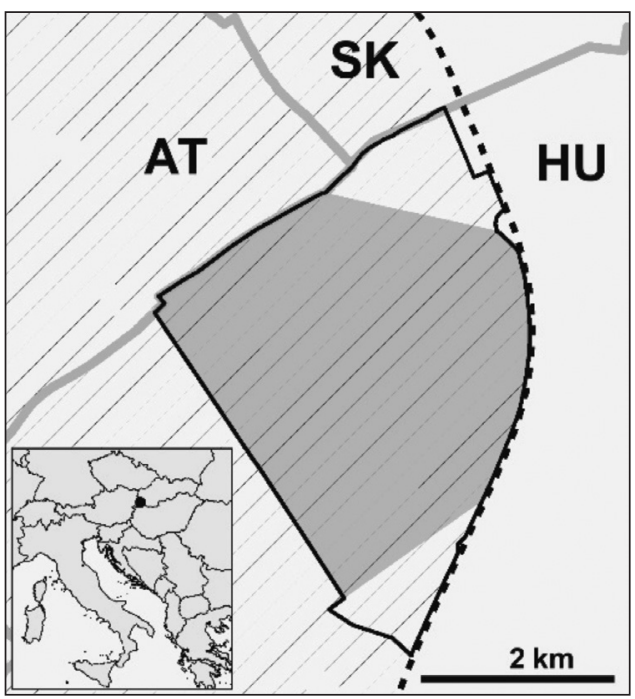

Figure 1. Schematic map and location of the study area. Solid black line - the study area; grey area - 'bustard counting area'; hatched area - Natura 2000 site; grey line - state border; dashed black line-highway; HU - Hungary; AT - Austria; SK - Slovakia

1. ábra A vizsgálati terület térképvázlata és elhelyezkedése. Folytonos fekete vonal - a vizsgálati terület; szürke mező - túzokszámolási terület; vonalkázott mező - Natura 2000 terület; szürke vonal - államhatár; szaggatott fekete vonal - autópálya; HU - Magyarország; AT Ausztria; SK - Szlovákia grown are cereals, maize and oilseed rape. The area is part of the 'High Nature Value Area', so local farmers can receive compensations for Great Bustard-friendly farming within the Hungarian Agri-Environmental Scheme. The total area of land cultivated in this way in the study area does not currently reach 100 ha $(<10 \%$ of the study area), these are typically extensively cultivated alfalfa fields.

The Great Bustard is an extremely sexually dimorphic bird (Alonso et al. 2009b), with lek mating system (Morales et al. 2001), and the parental care is exclusively undertaken by the females (Morales et al. 2002). In the spring, their favored habitat is usually cereals throughout their European range (Faragó 1987, Pescador \& Peris 1996, Moreira et al. 2004), and depending on whether they are available in their habitat: alfalfa, vetch, pastureland and fallow 
land (Faragó 1987, Pescador \& Peris 1996, Lane et al. 2001, Rocha et al. 2013). These are also the main breeding habitats (Petrick 1996, Morgado \& Moreira 2000, Rocha et al. 2013, Janó \& Végvári 2016).

The area fidelity to the breeding sites in female Great Bustards is very high (Alonso et al. 2000) and the natal dispersion is low (Martín et al. 2008). The Central European Great Bustard populations are considered as facultative migratory, indicating that their migration is triggered by harsh weather (Faragó 1990, Streich et al. 2006), however, a kind of seasonal movement is characteristic even for sedentary females (Alonso et al. 2000). Female Great Bustards can be observed in the study area from spring to autumn and they are not present in winter (own unpublished data), i.e. the place is of primary importance for reproduction.

\section{Method}

A direct and an indirect indicator are used for the spread of agricultural irrigation in the study area. The direct metric is the size of the irrigated area, which was measured only in 2019 and in 2020. The indirect metric is the length of permanently installed irrigation pipes which includes the Center-pivot (also called water-wheel or circle irrigation) and the lateral move (linear move, wheel move or side-roll) irrigation systems and furthermore the underground pipeline with hydrants supplying hose reel irrigation systems. These were measured during their construction. The accuracy of these data, thanks to intensive fieldwork, is estimated to be close to $100 \%$.

Habitat mapping was carried out in the study area every year between 2009 and 2020, during which we identified the main crop grown. Taking into account the irrigation characteristics and breeding site characteristics of a given crop, we grouped or treated them separately as follows: (1) soybean, (2) sugar beet, (3) sorghum species and millet (so far not suitable for breeding and grown almost exclusively by irrigation), (4) maize (not suitable for breeding, can be grown without irrigation, but is irrigated more and more frequently in recent years), (5) oilseed rape (the main winter food for Great Bustards in this region, but not suitable for breeding and recently increasingly irrigated), (6) autumn cereals (one of the most favored crop for breeding, typically grown without irrigation; only winter wheat and winter barley were included, other autumn cereals are usually sown for green fodder, which is not suitable for successful breeding), (7) alfalfa (perhaps the most important cultivated crop for breeding site in our area, the fields included in the study area are mainly supported by AES), (8) other crops (all other crops grown on smaller proportion, most of which are not preferred types of breeding habitats or cultivated in a not-Great Bustard-friendly way), (9) non-arable land (roads, wooded areas, water surface, orchard etc.), (10) unknown (the main crop grown is not known in that year). A suitable data set is not available from 2012.

At least once a month, a complete Great Bustard count was performed in the study area, classifying the individuals according to their sex (Spakovszky 2009). The study area is mainly significant as a breeding site, therefore we examined the spring presence of females. Most females appear at the breeding site in late March (Alonso et al. 2000), so only the counts after March $14^{\text {th }}$ were considered. The detection probability of the breeding females 
is limited due to the concealing behavior (Magaña et al. 2010). Therefore, in order to avoid a distortion (Sanz-Pérez et al. 2020), the results of the censuses after April $30^{\text {th }}$, when the majority of the females in our area are already incubating (Faragó 1983, Petrik 1996), were not taken into account. Despite the relatively small size of the study area, during the active spring period of the females, the whole area cannot be patrolled in such a way that double counting of individuals can be definitely excluded due to visual obstacles, thus the censuses of females were performed only in the 'bustard counting area' (Figure 1). This equals $83.7 \%$ of the study area. We provided the average and the standard deviation of the results of repeated censuses for the $15^{\text {th }}$ March $-30^{\text {th }}$ April period, and omitted the years (2012-2014, 2016, 2017), when the number of censuses covering the 'bustard counting area' was less than 3. The association of the number of Great Bustard females with the extent of irrigated area was measured by Pearson's correlation coefficient.

\section{Results}

Prior to 2018, the proportion of irrigated surface was below $10 \%$ of the study area each year as an estimated maximum according to our field observations. Since 2018, the area of irrigated lands increased rapidly, and by $2020,52 \%$ of the study area had been irrigated (Figure 2). The construction of Center-pivot and laterally moving linear irrigation systems as well as underground pipeline-hydrant systems began in 2017, of which the total length reached $2.3 \mathrm{~km}$ and $4.7 \mathrm{~km}$ in the study area till 2020, respectively. Since 2016, there has been an interest from farmers in irrigation, resulting in several water wells having been drilled in the study area, but these were not generally used at first (pers. obs.).

In the study area, new plant species appeared in the crop composition, such as soybeans, sugar beets, sorghum species and millet, which were mostly grown with irrigation (pers. obs.). The area proportion of these new crops was $30.6 \%$ in 2020 (Figure 2). The sown area of maize was significant in the past, too, but increased slightly as a result of irrigation. A major change in relation to maize is the widespread use of irrigation, with $84 \%$ of the maize fields area being irrigated in 2019 and $75.6 \%$ in 2020. The sown area of oilseed rape has decreased, which is assumed not to be related to irrigation, but to market processes making its cultivation less and less profitable in our region, however, it is also grown mainly with irrigation in recent years (pers. obs.). The area of autumn cereals has decreased from 30-40\% per year to about $20 \%$. The cultivation area of alfalfa is highly dependent on the AES, as alfalfa is grown almost exclusively on AES-supported arable land. In 2015, it barely reached $1 \%$ of the study area because that was an "interim year" between two periods when the AES was out of order. Nevertheless, despite being subsidized, it has never been grown in significant proportions and is even declining in the long run, which shows the competitiveness of intensive farming, including irrigation, against the AES. Furthermore, it was observed that in locations where a significant investment was made to build the new irrigation facility, crops typically grown without irrigation were also irrigated in many cases. For example, in $2020,40.3 \%$ of the winter wheat cultivation area was irrigated, which crop was typically not irrigated formerly. 


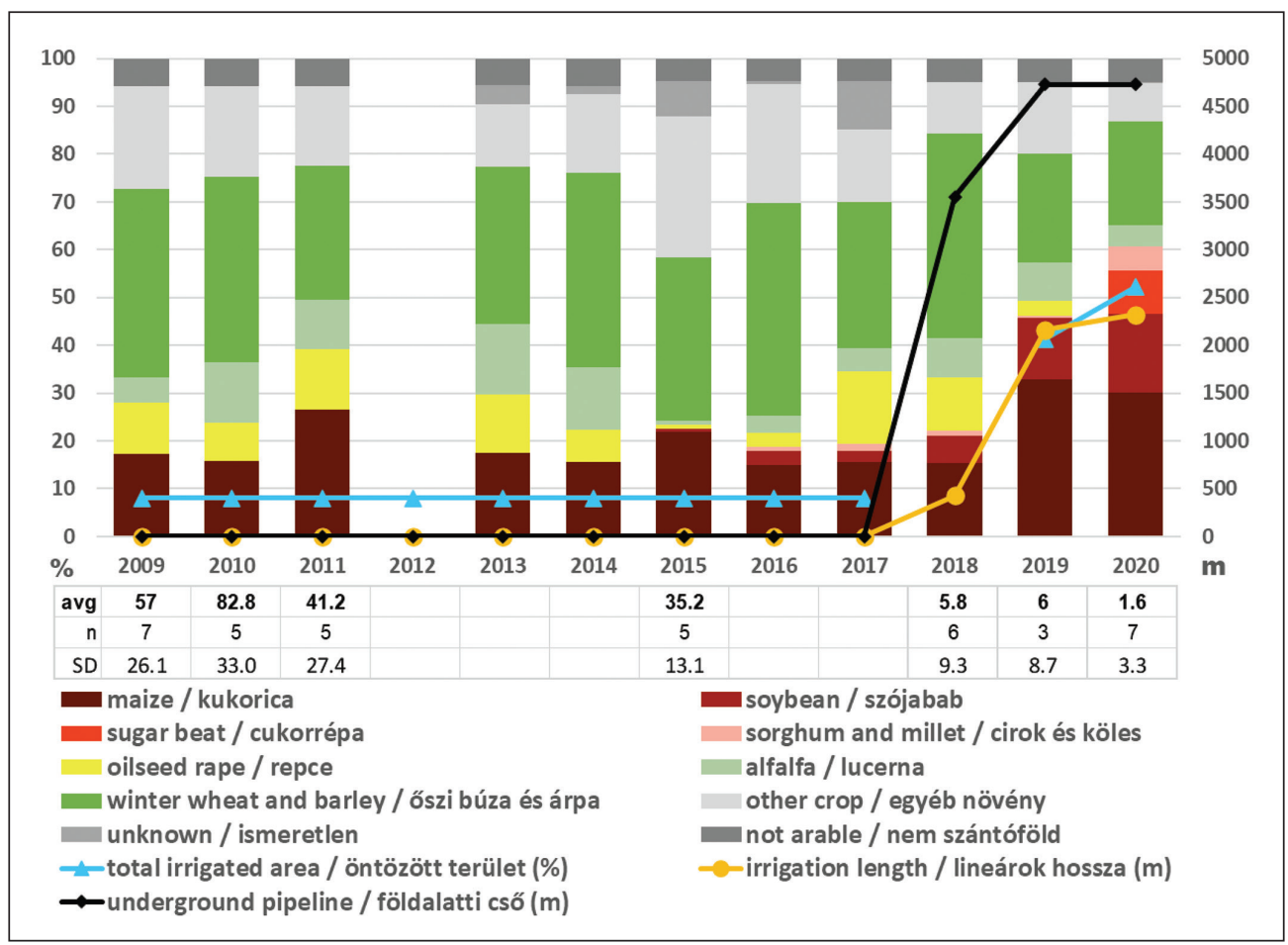

Figure 2. The crop composition and the proportion of the irrigated surface of the study area, the total length of the two main irrigation system, and the average number of the observed Great Bustard females (avg) in the counting area in the given years. $\mathrm{n}$ - the number of the Great Bustard counting events between $15^{\text {th }}$ March and $30^{\text {th }}$ April in the given year, SD standard deviation. The proportion of the irrigated surface before 2018 is expert estimation maximum

2. ábra A vizsgálati terület vetésszerkezete és az öntözött földek aránya, valamint a két fö öntözési rendszer hossza, illetve a túzokszámolási területen észlelt túzoktyúkok átlagos egyedszáma (avg) a vizsgálat éveiben. $\mathrm{n}$ - a túzokszámolási alkalmak száma március 15. és április 30. között az adott évben, SD - szórás. Az öntözött terület 2018 előtti értékei tapasztalati becsült maximumok

The number of Great Bustard females observed in the area in the spring decreased significantly during the study period. At the beginning of the study period, dozens of female Great Bustards were usually present in the study area in spring, on average 57 in 2009 $(\mathrm{SD}=26.1, \mathrm{n}=7), 32.8$ in $2010(\mathrm{SD}=33, \mathrm{n}=5)$ and 41.2 in $2011(\mathrm{SD}=27.4, \mathrm{n}=5)$. In contrast, it was seldom possible to count a dozen females at the end of the study period, on average 5.8 in $2018(\mathrm{SD}=9.3, \mathrm{n}=6), 6$ in $2019(\mathrm{SD}=8.7, \mathrm{n}=3)$ and 1.6 in $2020(\mathrm{SD}=3.3$, $\mathrm{n}=7$ ), respectively (Figure 2). No significant change other than the spread of irrigation and consequently the alteration of habitat structure was observed in the study area, and the decrease in the number of females is strongly correlated with it (Pearson's $r=-0.91$, $p=0.011)$. 


\section{Discussion}

As a result of our work, we demonstrate that irrigation farming in the study area has significantly increased in recent years, resulting to an increase in the proportion of crops that are unsuitable for breeding. In contrast, the proportion of favored breeding habitats has decreased, and thus it can be stated, that the quality of the bustard habitat has effectively deteriorated as a result of irrigation. Although only approximately half of the study area was irrigated, its negative effects are clearly detected on the intervening and adjacent non-irrigated lands, thus reducing the quality of the whole area (Brotons et al. 2004). Great Bustards are a long-lived species (Morales et al. 2002), so presumably individuals missing from the study area have been forced to other places, and a shrinking habitat may increase mortality and reduce reproduction rates (Morales et al. 2002). In the last two years, females have occurred mainly in the south-western and southern parts of the study area in the spring (pers. obs.), where better quality habitats are still available in the nearby fields. Great Bustards are expected to move less and less towards the study area, similarly to the experiences in Villafáfila, Spain, where less bustards moved south from the center compared to other directions because there were irrigated unsuitable habitats in significant extent (Alonso et al. 1995).

The West Pannonian Great Bustard population was driven to the verge of extinction in the second half of the $20^{\text {th }}$ century (Raab et al. 2010), but by investing a significant amount of energy and resources, we managed to reverse the declining trend and multiply the population in a short time (Faragó et al. 2014, Raab et al. 2014a). This unique result (Alonso 2014) is now threatened by an incompetently controlled agro-economic development (Palacín et al. 2012). Although the habitat-destroying effect of the spread of irrigated farming is clear, it is still feasible that it will remain hidden for a while at population level because the positive effects of diversified conservation activity may outweigh it (Gameiro et al. 2020).

As a kind of response to today's climate change, an increase in irrigated areas is expected in some parts of Europe (Riediger et al. 2014), e.g. in Hungary the goal is to quadruple the currently irrigated agricultural surface (Hungarian Government 2017). This direction is worrying in two ways. On the one hand, it means a further intensification of agriculture, which is already a serious problem for the ecosystem in general. On the other hand, climate change is expected to reduce access to irrigation water across Europe although to varying extent from region to region (Iglesias \& Garrote 2015), leading to an unsustainable shift in agriculture and generating conflicts by using limited water resources (Olesen et al. 2011, Moore \& Lobell 2014).

The situation of agro-steppe habitats and their species in NATURA 2000 areas is more favorable than outside, but negative processes also take place there (Silva et al. 2018, Gameiro et al. 2020). The general objectives of the Directives (Birds Directive 79/409/EEC, Habitats Directive 92/43/EEC) have not yet been met, but remain highly relevant and are still fit for the protection of species and habitats, as was recently concluded by an evaluation of the NATURA 2000 protection system (EC 2016). Therefore, the system needs to be maintained, further developed and supported (Gameiro et al. 2020). The authorities and organizations concerned must not disregard the original objectives in their management activities and procedures and must protect agro-steppe species and their habitats (Lane et al. 2001, Palacín et 
al. 2012). In Hungary, the sustainable land use of natural grasslands in NATURA 2000 sites has been regulated since 2007 (269/2007 government decree), which prohibits the irrigation of these grasslands. However, similar legislation on the sustainable management of NATURA 2000 arable land has not yet been implemented, which has to happen as soon as possible. Within this legislation, it is necessary to provide solutions for the appropriate reductions of harmful effects caused by an intensive agriculture, including irrigation.

Today, the Common Agriculture Policy of the EU is being redesigned, which is perhaps the main tool for moving European agriculture in the right direction. If we are to take biodiversity conservation seriously, the new agricultural policy must reflect on the challenges and take serious steps (Palacín \& Alonso 2018, Traba \& Morales 2019, Pe'er et al. 2020).

\section{Acknowledgements}

The study was completed thanks to the Fertö-Hanság National Park Directorate through the support of the long-term monitoring of the Great Bustard in the Mosoni-plain and with the partial contribution of the EU through the LIFE09 NAT/AT/000225 and LIFE15 NAT/ AT/000834 projects. We thank Clara Freytag, Alexander Bek and Maximilian Raab for their help during writing the article.

\section{References}

Alonso, J. C. 2014. The Great Bustard: past, present and future of a globally threatened species. - Ornis Hungarica 22(2): 1-13. DOI: 10.2478/orhu-2014-0014

Alonso, J. C., Alonso, J. A. \& Morales, M. 1995. Range and patterns of Great Bustard movements at Villafafila, NW Spain. - Ardeola 42(1): 69-76.

Alonso, J. C., Morales, M. B. \& Alonso, J. A. 2000. Partial migration, and lek and nesting area fidelity in female Great Bustards. - The Condor 102: 127-136.

Alonso, J. C., Palacín, C. \& Martín, C. A. 2003. Status and recent trends of the Great Bustard (Otis tarda) population in the Iberian peninsula. - Biological Conservation 110(2): 185-195. DOI: 10.1016/S00063207(02)00188-X

Alonso, J. C., Martín, C. A., Alonso, J. A., Palacín, C., Magaña, M., Lieckfeldt, D. \& Pitra, C. 2009a Genetic diversity of the Great Bustard in Iberia and Morocco: Risks from current population fragmentation. - Conservation Genetics 10(2): 379-390. DOI: 10.1007/s10592-008-9605-2

Alonso, J. C., Magaña, M., Alonso, J. A., Palacín, C., Martín, C. A. \& Martín, B. 2009b The most extreme sexual size dimorphism among birds: allometry, selection, and early juvenile development in the Great Bustard (Otis tarda). - The Auk 126(3): 657-665. DOI: 10.1525/auk.2009.08233

BirdLife International 2020. Species factsheet: Otis tarda. - Downloaded from http://www.birdlife.org on 25/09/2020.

Brotons, L., MaÑosa, S. \& Estrada, J. 2004. Modelling the effects of irrigation schemes on the distribution of steppe birds in Mediterranean farmland. - Biodiversity and Conservation 13(5): 1039-1058. DOI: 10.1023/B:BIOC.0000014468.71368.35

De Frutos, A., Olea, P. P. \& Mateo-Tomás, P. 2015. Responses of medium- and large-sized bird diversity to irrigation in dry cereal agroecosystems across spatial scales. - Agriculture, Ecosystems \& Environment 207: 141152. DOI: $10.1016 /$ j.agee.2015.04.009

Donald, P. F., Green, R. E. \& Heath, M. F. 2001. Agricultural intensification and the collapse of Europe's farmland bird populations. - Proceedings of the Royal Society of London. Series B: Biological Sciences 268(1462): 25-29. DOI: $10.1098 /$ rspb.2000.1325 
Dudley, N. \& Alexander, S. 2017. Agriculture and biodiversity: A review. - Biodiversity, 18(2-3): 45-49. DOI: $10.1080 / 14888386.2017 .1351892$

EC (European Commission) 2009. Great Bustard, Otis tarda factsheet. - EU Wildlife and Sustainable Farming project 2009

EC (European Commission) 2016. Fitness check of the EU Nature Legislation (Birds and Habitats Directives). - Downloaded from: https:/ec.europa.eu/environment/nature/legislation/fitness_check/docs/nature_fitness check.pdf on 25/09/2020.

Faragó, S. 1983. A túzok (Otis t. tarda L.) fészkelésbiológiája Magyarországon [The breeding ecology of Great Bustard (Otis t. tarda L.) in Hungary]. - Állattani Közlemények 70: 33-38. (in Hungarian)

Faragó, S. 1987. A növényzet szerepe a túzok (Otis tarda tarda Linné, 1785) elterjedésében és költésbiológiájában Magyarországon [The role of the vegetation in the spreading and hatching biology of Bustard (Otis tarda Linné, 1785) in Hungary]. - Erdészeti és Faipari Tudományos Közlemények 1986(1): 177-213. (in Hungarian with English Summary)

Faragó, S. 1990. A kemény telek hatása Magyarország túzok (Otis tarda L.) állományára [The effect of heavy winters on Bustard (Otis tarda L.) populations in Hungary]. - Állattani Közlemények 76: 51-62. (in Hungarian with English Summary)

Faragó, S. 2006. One-hundred-year trend of the Great Bustard (Otis tarda) population in the Kisalföld Region. Aquila 112: 153-162.

Faragó, S., Spakovszky, P. \& Raab, R. 2014. Conservation of Great Bustard (Otis tarda) population of the Mosoni-Plain - A success story. - Ornis Hungarica 22(2): 14-31. DOI: 10.2478/orhu-2014-0015

Gameiro, J., Silva, J. P., Franco, A. M. A. \& Palmeirim, J. M. 2020. Effectiveness of the European Natura 2000 network at protecting Western Europe's agro-steppes. - Biological Conservation 248: 108681. DOI: 10.1016/j.biocon.2020.108681

Glutz, U. N., Bauer, K. M. \& Bezzel, E. 1973. Otis tarda Linné 1758 - Großtrappe [Otis tarda Linné 1758 - Great Bustard]. - In: Handbuch der Vögel Mitteleuropas, Vol. 5. Aula Verlag Wiesbaden (2 ${ }^{\text {nd }}$ reviewed ed. 1994), pp. 649-688. (in German)

Horreo, J. L., Palacín, C., Alonso, J. C. \& Milá, B. 2013. A link between historical population decline in the threatened Great Bustard and human expansion in Iberia: Evidence from genetic and demographic data. - Biological Journal of the Linnean Society 110(3): 518-527. DOI: 10.1111/bij.12152

Hungarian Government 2017. Nemzeti Vízstratégia (Kvassay Jenő Terv) [National Water Strategy (Jenő Kvassay Plan)]. - Budapest - Downloaded from: https://www.kormany.hu/download/6/55/01000/Nemzeti\%20 V\%C3\%ADzstrat\%C3\%A9gia.pdf on 25/09/2020. (in Hungarian)

Iglesias, A. \& Garrote, L. 2015. Adaptation strategies for agricultural water management under climate change in Europe. - Agricultural Water Management 155: 113-124. DOI: 10.1016/j.agwat.2015.03.014

Janó, G. \& Végvári, Zs. 2016. Nest site selection of the Great Bustard (Otis t. tarda) in Körös-Maros National Park, Eastern Hungary. - Ornis Hungarica 24(2): 32-45. DOI: 10.1515/orhu-2016-0013

Jerrentrup, J. S., Dauber, J., Strohbach, M. W., Mecke, S., Mitschke, A., Ludwig, J. \& Klimek, S. 2017. Impact of recent changes in agricultural land use on farmland bird trends. - Agriculture, Ecosystems \& Environment 239: 334-341. DOI: 10.1016/j.agee.2017.01.041

Lane, S. J., Alonso, J. C. \& Martín, C. A. 2001. Habitat preferences of Great Bustard Otis tarda flocks in the arable steppes of central Spain: Are potentially suitable areas unoccupied? - Journal of Applied Ecology 38: 193-203. DOI: 10.1046/j.1365-2664.2001.00577.x

Magaña, M., Alonso, J. C., Martín, C. A., Bautista, L. M. \& Martín, B. 2010. Nest-site selection by Great Bustards Otis tarda suggests a trade-off between concealment and visibility: Nesting habitat selection by Great Bustards. - Ibis 152(1): 77-89. DOI: 10.1111/j.1474-919X.2009.00976.x

Martín, C. A., Alonso, J. C., Alonso, J. A., Palacín, C., Magaña, M. \& Martín, B. 2008. Natal dispersal in Great Bustards: The effect of sex, local population size and spatial isolation. - Journal of Animal Ecology 77(2): 326-334. DOI: 10.1111/j.1365-2656.2007.01349.x

Martín, C. A., Martínez, C., Bautista, L. M. \& Martin, B. 2012a Population increase of the Great Bustard Otis tarda in its main distribution area in relation to changes in farming practices. - Ardeola 59(1): 31-42. DOI: 10.13157/arla.59.1.2012.31

Martín, B., Alonso, J. C., Martín, C. A., Palacín, C., Magaña, M. \& Alonso, J. 2012b Influence of spatial heterogeneity and temporal variability in habitat selection: A case study on a Great Bustard metapopulation. - Ecological Modelling 228: 39-48. DOI: 10.1016/j.ecolmodel.2011.12.024 
Miklay, F. \& Molnár, L. 1968. A Mosoni-síkság talajviszonyai [Soil characteristics of the Mosoni-plain]. Agrokémia és Talajtan 17(4): 495-506. (in Hungarian)

Moore, F. C. \& Lobell, D. B. 2014. Adaptation potential of European agriculture in response to climate change. Nature Climate Change 4(7): 610-614. DOI: 10.1038/nclimate2228

Morales, M. B., Alonso, J. C. \& Alonso, J. 2002. Annual productivity and individual female reproductive success in a Great Bustard Otis tarda population. - Ibis 144: 293-300. DOI: 10.1046/j.1474-919X.2002.00042.x

Morales, M. B., Jiguet, F. \& Arroyo, B. 2001. Exploded leks: what Bustards can teach us. - Ardeola 48(1): 85-98.

Moreira, F., Morgado, R. \& Arthur, S. 2004. Great Bustard Otis tarda habitat selection in relation to agricultural use in southern Portugal. - Wildlife Biology 10(1): 251-260. DOI: 10.2981/wlb.2004.030

Morgado, R. \& Moreira, F. 2000. Seasonal population dynamics, nest site selection, sex-ratio and clutch size of the Great Bustard Otis tarda in two adjacent lekking areas. - Ardeola 47(2): 237-246.

Olesen, J. E., Trnka, M., Kersebaum, K. C., Skjelvåg, A. O., Seguin, B., Peltonen-Sainio, P., Rossi, F., Kozyra, J. \& Micale, F. 2011. Impacts and adaptation of European crop production systems to climate change. - European Journal of Agronomy 34(2): 96-112. DOI: 10.1016/j.eja.2010.11.003

Palacín, C., Alonso, J. C., Martín, C. A. \& Alonso, J. A. 2012. The importance of traditional farmland areas for steppe birds: A case study of migrant female Great Bustards Otis tarda in Spain. - Ibis 154(1): 85-95. DOI: 10.1111/j.1474-919X.2011.01183.x

Palacín, C. \& Alonso, J. C. 2018. Failure of EU Biodiversity Strategy in Mediterranean farmland protected areas. - Journal for Nature Conservation 42: 62-66. DOI: 10.1016/j.jnc.2018.02.008

Pe'er, G., Bonn, A., Bruelheide, H., Dieker, P., Eisenhauer, N., Feindt, P. H., Hagedorn, G., Hansjürgens, B., Herzon, I., Lomba, Â., Marquard, E., Moreira, F., Nitsch, H., Oppermann, R., Perino, A., Röder, N., Schleyer, C., Schindler, S., Wolf, C., Zinngrebe, Y. \& Lakner, S. 2020. Action needed for the EU Common Agricultural Policy to address sustainability challenges. - People and Nature 2(2): 305-316. DOI: 10.1002/pan3.10080

Pescador, M. \& Peris, S. J. 1996. Selección del hábitat por la Avutarda (Otis tarda) en campos agrícolas del centro-oeste de la Península Ibérica [Habitat selection of Great Bustard (Otis tarda) in agricultural environment in West-Central Iberian Peninsula]. - Ecología 10: 471-480. (in Spanish with English Summary)

Petrick, S. 1996. Zur Brutplatzwahl der Großtrappe (Otis t. tarda L., 1758) im Land Brandenburg [Breeding habitat selection of Great Bustard (Otis t. tarda L., 1758) in Brandenburg State, Germany]. - Naturschutz und Landschaftspflege in Brandenburg 5(1-2): 99-102. (in German with English Summary)

Pinto, M., Rocha, P. \& Moreira, F. 2005. Long-term trends in Great Bustard (Otis tarda) populations in Portugal suggest concentration in single high quality area. - Biological Conservation 124(3): 415-423. DOI: 10.1016/j.biocon.2005.01.047

Pitra, C., Suárez-Seoane, S., Martín, C. A., Streich, W-J. \& Alonso, J. C. 2011. Linking habitat quality with genetic diversity: A lesson from Great Bustards in Spain. - European Journal of Wildlife Research 57(3): 411419. DOI: $10.1007 / \mathrm{s} 10344-010-0447-0$

Raab, R., Julius, E., Greis, L., Schütz, C., Spakovszky, P., Steindl, J. \& Schönemann, N. 2014a Endangering factors and their effect on adult Great Bustards (Otis tarda). - Conservation efforts in the Austrian LIFE and LIFE+ projects. - Aquila 121: 49-63.

Raab, R., Julius, E., Greis, L., Schütz, C., Spakovszky, P., Steindl, J. \& Schönemann, N. 2014b The Austrian agri-environmental scheme for Great Bustard (Otis tarda). - Aquila 121: 95-102.

Raab, R., Kollar, H. P., Winkler, H., Faragó, S., Spakovszky, P., Chavko, J., Maderič, B., Škorpíková, V., Patak, E., Wurm, H., Julius, E., Raab, S. \& Schütz, C. 2010. Die Bestandsentwicklung der westpannonischen Population der Großtrappe, Otis tarda Linnaeus 1758, von 1900 bis zum Winter 2008/2009 [Development of the West Pannonian population of the Great Bustard, Otis tarda Linnaeus 1758, from 1900 to the winter 2008/2009]. - Egretta 51: 74-99. (in German with English Summary)

Reidsma, P., Tekelenburg, T., van den Berg, M. \& Alkemade, R. 2006. Impacts of land-use change on biodiversity: An assessment of agricultural biodiversity in the European Union. - Scenario-Based Studies of Future Land Use in Europe 114(1): 86-102. DOI: 10.1016/j.agee.2005.11.026

Riediger, J., Breckling, B., Nuske, R. S. \& Schröder, W. 2014. Will climate change increase irrigation requirements in agriculture of Central Europe? A simulation study for Northern Germany. - Environmental Sciences Europe 26(1): 18. DOI: 10.1186/s12302-014-0018-1

Rocha, P., Morales, M. B. \& Moreira, F. 2013. Nest site habitat selection and nesting performance of the Great Bustard Otis tarda in southern Portugal: Implications for conservation. - Bird Conservation International 23(3): 323-336. DOI: 10.1017/S0959270912000202 
Sanz-Pérez, A., Sollmann, R., Sardà-Palomera, F., Bota, G. \& Giralt, D. 2020. The role of detectability on bird population trend estimates in an open farmland landscape. - Biodiversity and Conservation 29(6): 17471765. DOI: 10.1007/s10531-020-01948-0

Silva, J. P., Correia, R., Alonso, H., Martins, R. C., D’Amico, M., Delgado, A., Sampaio, H., Godinho, C. \& Moreira, F. 2018. EU protected area network did not prevent a country wide population decline in a threatened grassland bird. - PeerJ 6: e4284. DOI: 10.7717/peerj.4284

Spakovszky, P. 2009. Túzok (Otis tarda) állományának monitoringja a LIFE programban [Monitoring of the Great Bustard (Otis tarda) population in the LIFE-project]. - Szélkiáltó 14: 21. (in Hungarian with English Summary)

Streich, W. J., Litzbarski, H., Ludwig, B. \& Ludwig, S. 2006. What triggers facultative winter migration of Great Bustard (Otis tarda) in Central Europe? - European Journal of Wildlife Research 52(1): 48-53. DOI: 10.1007/s10344-005-0007-1

Szabó, K., Bozsó, M., Boros, E. \& Pénzes, Z. 2007. A túzok hazai populációinak genetikai változatossága [Genetic diversity of the Hungarian Great Bustard populations]. - In: Forró, L. (ed.) A Kárpát-medence állatvilágának kialakulása [The evolution of the fauna in Carpathian Basin]. - Magyar Természettudományi Múzeum, Budapest, pp. 297-302. (in Hungarian)

Szenek, Z. \& Végvári, Zs. 2018. Habitat selection of the Great Bustard (Otis tarda) in Körös-Maros National Park. - Ornis Hungarica 26(1): 89-94. DOI: 10.1515/orhu-2018-0006

Teillard, F., Jiguet, F. \& Tichit, M. 2015. The response of farmland bird communities to agricultural intensity as influenced by its spatial aggregation. - PLOS ONE 10(3): e0119674. DOI: 10.1371/journal.pone.0119674

Török, P., Neuffer, B., Heilmeier, H., Bernhardt, K-G. \& Wesche, K. 2020. Climate, landscape history and management drive Eurasian steppe biodiversity. - Flora 271: 151685. DOI: 10.1016/j.flora.2020.151685

Traba, J. \& Morales, M. B. 2019. The decline of farmland birds in Spain is strongly associated to the loss of fallowland. - Scientific Reports 9(1): 9473. DOI: 10.1038/s41598-019-45854-0

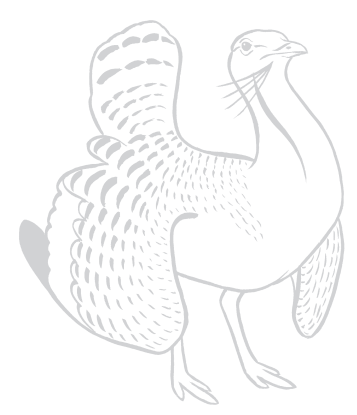

